\title{
Geospatial Assessment of Crop Water Requirement for Yield Optimization of Oil Palm in South West Nigeria
}

\section{Isa Ibrahim ${ }^{\star 1}$, Orewole O. Maruf², Abayomi T. Alaga ${ }^{1}$}

${ }^{1}$ Cooperative Information Network, National Space Research and Development Agency, Obafemi Awolowo University, Ile-Ife, Nigeria.

${ }^{2}$ National Centre for Technology Management (NACETEM), Federal Ministry of Science and Technology, Obafemi Awolowo University, Ile-Ife, Nigeria.

\section{ARTICLE INFO}

Article No.: 071316118

DOI: 10.15580/GJAS.2016.7.071316118

Submitted: 13/07/2016

Accepted: 20/07/2016

Published: 05/08/2016

${ }^{*}$ Corresponding Author

Isa Ibrahim

E-mail: ibrahisa@yahoo.com

\section{Keywords:}

Crop water requirement, irrigation, yield optimization, agro ecological zones
Oil palm is a very important crop because of many products that are generated from it, which can boost the economy of Nigeria and create job opportunities for teeming Nigerian youths. The crop is being cultivated, although not maximum capacity, in many areas of the country. The major factors considered in oil palm cultivation are soil type and climate especially temperature and rainfall. This study assessed the crop water requirements for yield optimization of oil palm in Southwest Nigeria. The study showed that the greater percentage of the Southwest Nigeria is suitable for the crop's cultivation. However, the crop water requirements of oil palm increase northwards from the humid forest zone to the Sahel savannah zone of the study area. Moisture is available for oil palm's utilization in the savannah region but not in abundant quantity as in the southern humid forest zone. Irrigation requirements increase from humid forest agro ecological zone to the Sahel savannah zone. The study therefore suggests that yield optimization could be achieved through complementing the rainfall with irrigation water. 


\section{INTRODUCTION}

The oil palm, Elaeis guineensis is a perennial crop that is traced to the tropical rain forest of West Africa (Olagunju, 2008). Its spread reached South America and then to Asia in the 16th and 19th century respectively. Palm oil is edible plant oil derived from its fruits. Palm oil is one of the few vegetable oils that contains relatively high content of saturated fats, thus it is semi-solid at room temperature. The oil is widely used as cooking oil and is very important in food industries as well as soap and personal care industries. Oil palm is a perennial crop which starts to yield about 3 to 4 years after planting and its average economic lifetime of about 25 years. Although higher yield could be obtained from a wellmanaged plantation, its average peak yield is within the range of 25-28 ton/ha (Gurmit, 1999).

The natural habitat of oil palm is riverine forests or freshwater swamps. However, it has adapted to diverse ecological zones in the tropical belt (long. $15^{\circ} \mathrm{N}-$ $\left.15^{\circ} \mathrm{S}\right)$, from savannah to rainforest and highlands (< $1500 \mathrm{~m}$ ) although it is widely grown on lowlands. The crop grows on most tropical soils with adequate water supply. Slightly acidic soils with $\mathrm{pH} 4-6$ and slopes of $<$ $20^{\circ}$ are suitable. The crop can withstand annual rainfall between 650 and $4500 \mathrm{~mm}$ with 2-4 months of dry period although the ideal rainfall is $2000-2500$ $\mathrm{mm} /$ year without any dry season. The suitable temperatures for oil palm is a mean maximum temperature of $28-34^{\circ} \mathrm{C}$ and mean minimum temperature of $21-24^{\circ} \mathrm{C}$. Oil palm requires full sunlight for maximum photosynthesis and sunshine hours should exceed $5 \mathrm{~h} /$ day or $1825 \mathrm{~h} /$ year provided the high sunshine hours are not accompanied by drought, high water vapour pressure deficit (>1.8 $\mathrm{kPa}$ ) and/or extreme temperatures $\left(>38^{\circ} \mathrm{C}\right)$ while the solar radiation should be at least $12 \mathrm{MJ} / \mathrm{m} 2 /$ day (Janick and Paull, 2008). In addition, fertilizer demands are moderate compared to other industrial crops and are mainly for compensating the nutrients harvested in the fruit bunches.

While Nigeria has the capability of being the leading producer of palm oil globally, this is no longer the situation as the country is far behind Malaysia and Indonesia who have emerged as major producers of palm oil (FAO, 1986). This decline cannot be divorced from the discovery of crude oil and neglect suffered by the agricultural sector thereafter. Kei et al (1997) observed that the success of the Oil palm sector in Malaysia is built on sustainable plantation management together and adoption of modern processing technologies.

Many youths are disinterested in farming because of this neglect, seemingly the unprofitable nature of the sector because of lack of adequate information and modern knowledge - based agricultural practices such as advanced information about crop water requirement (CWR). Since climate has a great effect on the sustainability of the all crops including oil palm, knowledge of climate-suitability is very important before investing in its cultivation. However, many farmers embark on oil palm cultivation without the knowledge of the climatic requirements of the crops they intend to cultivate. Understanding climate-suitability and crop water requirement of oil palm cultivation in the south western part of Nigeria could go a long way in stimulating intense investment in its cultivation and higher yield resulting from adequate irrigation water management. This will in turn boost the economic situation of the rural and urban population (CBN/ NISER, 1992) and create more jobs along the value chain of palm oil processing.

This study therefore aimed to determine the climate-suitability of the study area and crop water requirement $(\mathrm{CRW})$ for oil palm cultivation with the view of expanding potential cultivable areas and determining irrigation requirements using geoinformatics and Food and Agriculture Organization's Penman-Monteith method embedded in CROPWAT 8.0 software.

\section{Aim and Objective}

The aim of this study is to evaluate the water availability for optimal yield with respect to crop water requirement of oil palm in Southwest Nigeria.

The specific objectives are:

1. To analyze the degree of climate-suitability of the study area for oil palm cultivation;

2. To analyze the variation in the water available with respect to the crop water required for optimal yield in the study area; and

3. To generate suitability map and irrigation map for optimal yield of oil palm.

\section{Significance of the Study}

The result of this study will enable policy makers in the area of agriculture and youth empowerment to look into how oil palm cultivation could help improve the nation's economy and create jobs for our teeming youth population. It will also enable water resources managers allocate more water to cater for the deficit in crop water requirement for oil palm cultivation across the region. The study will also contribute to knowledge in the area of crop management and provide a framework for food security and irrigation management.

\section{METHODOLOGY}

\section{Description of the Study Area}

The study area lies between latitude $50^{\circ} 49^{\prime}$ and $9012^{\prime} \mathrm{N}$ of the equator and longitude $3^{\circ} 15^{\prime}$ and $6^{\circ} 3^{\prime} \mathrm{E}$ of the 
Greenwich Meridian and located in the Southwest zone of Nigeria (Figure 1). It is divided into six states namely Ekiti, Lagos, Ogun, Ondo, Osun and Oyo. The study area has three main agroecological zones (Figure 2) that support oil palm production - Humid Forest, Derived Savannah and Southern Guinea Savannah being situated in the tropical belt of longitude $15^{\circ} \mathrm{N}-15^{\circ} \mathrm{S}$ (Janick and Paull, 2008).

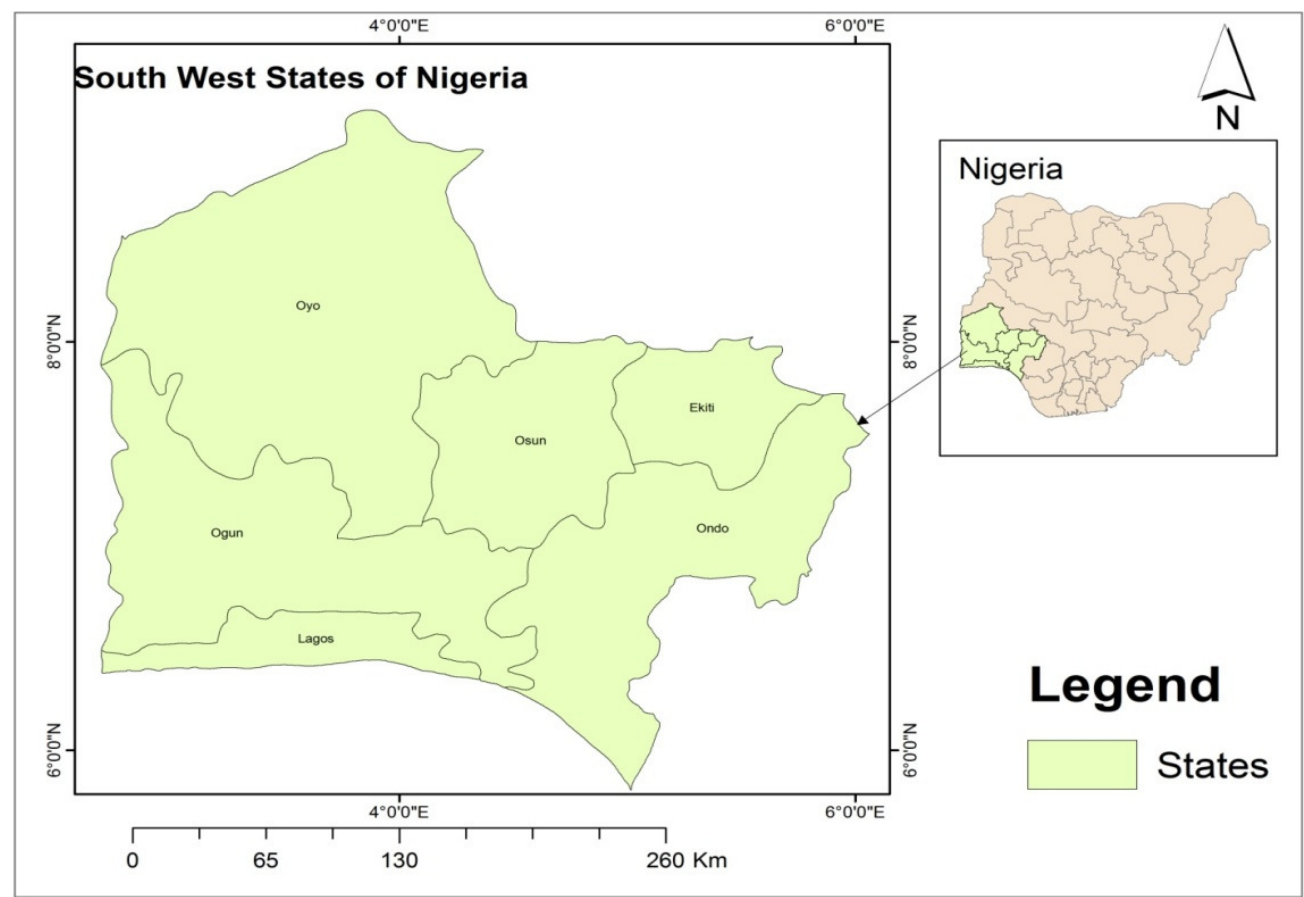

Figure 1: Southwest Nigeria showing the six states

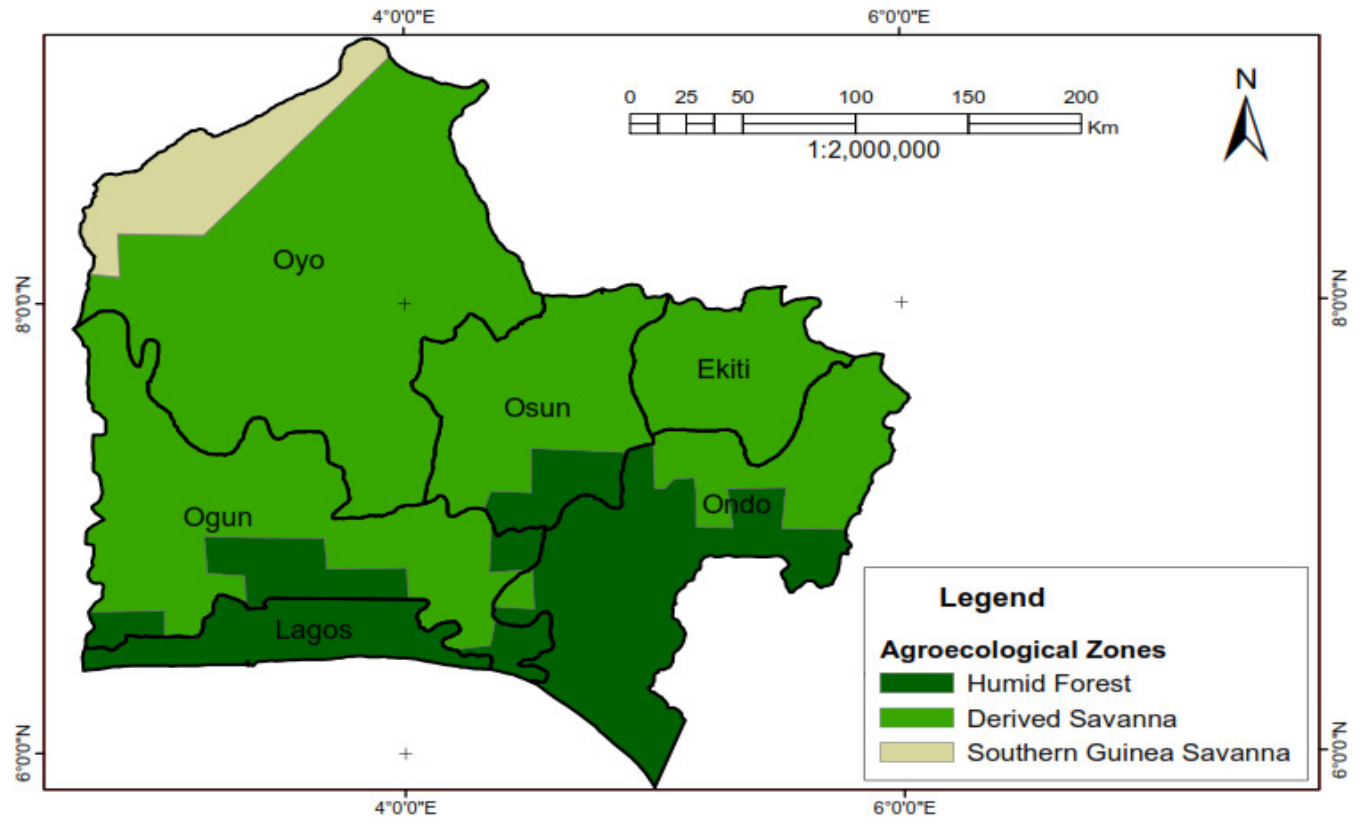

Figure 2: The agro ecological zones in Southwest Nigeria 


\section{Climate Suitability Analysis of the Study Area for Oil Palm Cultivation}

To determine the climate suitability of the study area for oil palm cultivation, climatic data of mean annual rainfall, mean minimum temperature and mean maximum temperature obtained from the fixed weather stations were interpolated and rasterized using ArcGIS 10.0 software. The results of the climatic data were reclassified to exclude unsuitable regions using the following criterion: Mean annual rainfall $(650-4500$ $\mathrm{mm})$, mean minimum temperature $\left(21-24^{\circ} \mathrm{C}\right)$, mean maximum temperature $\left(28-34^{\circ} \mathrm{C}\right)$, average sunshine hours ( $>5 \mathrm{~h} /$ day), and solar radiation ( $\geq 12 \mathrm{MJ} / \mathrm{m} 2 /$ day). Overlay analysis was carried out to determine climate suitable areas.

\section{Crop Water Requirement (CRW) and Irrigation Requirement (IR) Analyses}

Determination of Crop Water Requirement (CWR) for oil palm was achieved using Penman-Monteith method of the CROPWAT 8.0 software taking into consideration, the reference evapotranspiration (ETo), soil type, field capacity, permanent wilting point and effective root zone of the crops. The CROPWAT model calculated the CWR by solving the following equations:

$$
C W R_{i}=\sum_{t=0}^{T}\left(K c_{i} * E T_{o}-P_{e f f}\right)
$$

Where $\mathrm{Kc}_{\mathrm{i}}$ is the crop coefficient of the given crop $i$ during the growth stage which ranges between $t$ and $T$, and $P_{\text {eff }}$ is the effective rainfall while $E T_{o}$ is the reference crop evapotranspiration (in $\mathrm{mm} /$ day) which is defined by the equation below:

$$
E T_{o}=\frac{0.408 \Delta\left(R_{n}-G\right)+\gamma \frac{900}{T+273} \mathrm{U}_{2}\left(e_{s}-e_{a}\right)}{\Delta+\gamma\left(1+0.34 \mathrm{U}_{2}\right)}
$$

Where: $E T_{o}=$ reference evapotranspiration $\left[\mathrm{mm} \mathrm{day}^{-1}\right]$; $R_{n}=$ net radiation at the crop surface [MJ m${ }^{-2}$ day $\left.^{-1}\right] ; G=$ soil heat flux density [MJ $\mathrm{m}^{-2}$ day $^{-1}$ ]; $T=$ mean daily air temperature at $2 \mathrm{~m}$ height $\left[{ }^{\circ} \mathrm{C}\right] ; \mathrm{U}_{2}=$ wind speed at $2 \mathrm{~m}$ height $\left[\mathrm{ms}^{-1}\right] ;$ es $=$ saturation vapour pressure $[\mathrm{kPa}] ; e_{a}=$ actual vapour pressure $[\mathrm{kPa}] ; e_{s}-e_{a}=$ saturation vapour pressure deficit $[\mathrm{kPa}] ; \Delta=$ slope vapour pressure curve $\left[\mathrm{kPa}^{\circ} \mathrm{C}^{-1}\right]$ and $\mathrm{y}=$ psychrometric constant $\left[\mathrm{kPa}{ }^{\circ} \mathrm{C}-\right.$ $\left.{ }^{1}\right]$.

Irrigation requirement will compensate for the moisture deficit of the oil palm water requirement during the growth stages for optimal performance of the crop in terms of yield. Irrigation requirement was estimated by the software considering the initial soil moisture and the crop water requirement and effective rainfall.

\section{RESULTS AND DISCUSSION}

Net radiation at the crop surface $\left(R_{n}\right)$ and Reference evapotranspiration $\left(E T_{o}\right)$ were estimated by CROPWAT 8.0 model and the result for lbadan station is shown in Table 1 as an example. The $E T_{o}$ ranges between 2.92 and $4.49 \mathrm{~mm} /$ day while the average value is 3.78 $\mathrm{mm} /$ day while the net radiation flux $R_{n}$ ranges between 13.7 and $19.1 \mathrm{MJ} / \mathrm{m}^{2} /$ day and the average value is 16.8 $\mathrm{MJ} / \mathrm{m}^{2} /$ day. It is observed that the reference evapotranspiration increases from January up till February before the onset of rainfall in March and then decreases downward till August due to increase in precipitation.

Table 1: Meteorological Data of Ibadan, Oyo State for estimating $\boldsymbol{R}_{n}$ and $E T_{o}$

\begin{tabular}{|c|r|r|r|r|r|r|r|r|}
\hline Month & \multicolumn{1}{|c|}{ Min Temp } & \multicolumn{1}{c|}{ Max Temp } & Precipitation & Humidity & \multicolumn{1}{l|}{ Wind } & \multicolumn{1}{c|}{ Sun } & \multicolumn{1}{c|}{ Rad } & $\mathrm{ET}_{\circ}$ \\
\hline & \multicolumn{1}{c}{${ }^{\circ} \mathrm{C}$} & ${ }^{\circ} \mathrm{C}$ & $\mathrm{mm}$ & \multicolumn{1}{c}{$\%$} & $\mathrm{~m} / \mathrm{s}$ & \multicolumn{1}{c|}{ hours } & $\mathrm{MJ} / \mathrm{m}^{2} /$ day & $\mathrm{mm} /$ day \\
\hline January & 21.1 & 32.8 & 4 & 65 & 1.20 & 6.3 & 17.3 & 4.04 \\
\hline February & 21.7 & 33.9 & 23 & 62 & 1.20 & 6.8 & 19 & 4.49 \\
\hline March & 22.8 & 33.9 & 83 & 67 & 1.00 & 6.3 & 19.1 & 4.46 \\
\hline April & 22.8 & 32.8 & 150 & 68 & 0.80 & 6 & 18.7 & 4.23 \\
\hline May & 22.2 & 31.7 & 156 & 73 & 0.80 & 6.1 & 18.3 & 4.04 \\
\hline June & 21.7 & 29.4 & 182 & 76 & 0.80 & 5.3 & 16.7 & 3.59 \\
\hline July & 21.1 & 27.8 & 173 & 79 & 0.50 & 3.5 & 14.2 & 2.98 \\
\hline August & 20.5 & 27.2 & 147 & 79 & 0.80 & 2.9 & 13.7 & 2.92 \\
\hline September & 21.7 & 28.9 & 183 & 76 & 0.80 & 3.5 & 14.7 & 3.18 \\
\hline October & 22.2 & 30 & 179 & 73 & 0.80 & 5.5 & 17.1 & 3.64 \\
\hline November & 21.7 & 31.7 & 29 & 70 & 1.00 & 6.6 & 17.9 & 3.91 \\
\hline December & 20.5 & 32.8 & 7 & 67 & 1.00 & 6.7 & 17.4 & 3.86 \\
\hline & & & & & & & & \\
\hline Average & 21.67 & 31.08 & 109.67 & 71.25 & 0.89 & 5.46 & 17.01 & 3.78 \\
\hline
\end{tabular}


The crop water requirements of (CWR) for oil palm in different climatic zones surrounding the Southwestern Nigeria are shown in Table 2. The values range from $1138.6 \mathrm{~m}^{3} /$ ha in Station 4 that is located in the humid forest (HF) agroecological zone to $1571.9 \mathrm{~m}^{3} / \mathrm{ha}$ in Station 3, that is within Derived savannah (DS). The spatial variation in CWR of oil palm across the six Southwestern states is shown in Figure 5. It is observed that the crop water requirements increase northwards from the Humid Forest zone to the Derived Savannah zone and they correspond to the temperature variations as presented in Figures 3 and 4.

Table 2: Crop Water Required (CWR), Effective Rainfall (ER) and Irrigation Requirements (IR) for 5 Weather Stations

\begin{tabular}{|c|c|c|c|c|c|c|}
\hline No & Station & State & $\begin{array}{c}\text { Agroecological } \\
\text { Zone }\end{array}$ & $\begin{array}{c}\text { CRW } \\
\left(\mathrm{m}^{3} / \mathrm{ha}\right)\end{array}$ & ER $\left(m^{3} / h a\right)$ & IR $\left(\mathrm{m}^{3} / \mathrm{ha}\right)$ \\
\hline 1 & Ibadan & Oyo & DS & 1234.1 & 987.6 & 426 \\
\hline 2 & Ikeja & Lagos & $\mathrm{HF}$ & 1143 & 1046.6 & 361.2 \\
\hline 3 & Illorin & Kwara & DS & 1571.9 & 895.2 & 743.8 \\
\hline 4 & Benin-city & Edo & $\mathrm{HF}$ & 1138.6 & 1240.8 & 259.7 \\
\hline 5 & Lokoja & Kogi & DS+SGS & 1329.9 & 891.7 & 571.8 \\
\hline
\end{tabular}

HF=Humid Forest; DS=Derived Savannah; SGS=Southern Guinea Savannah

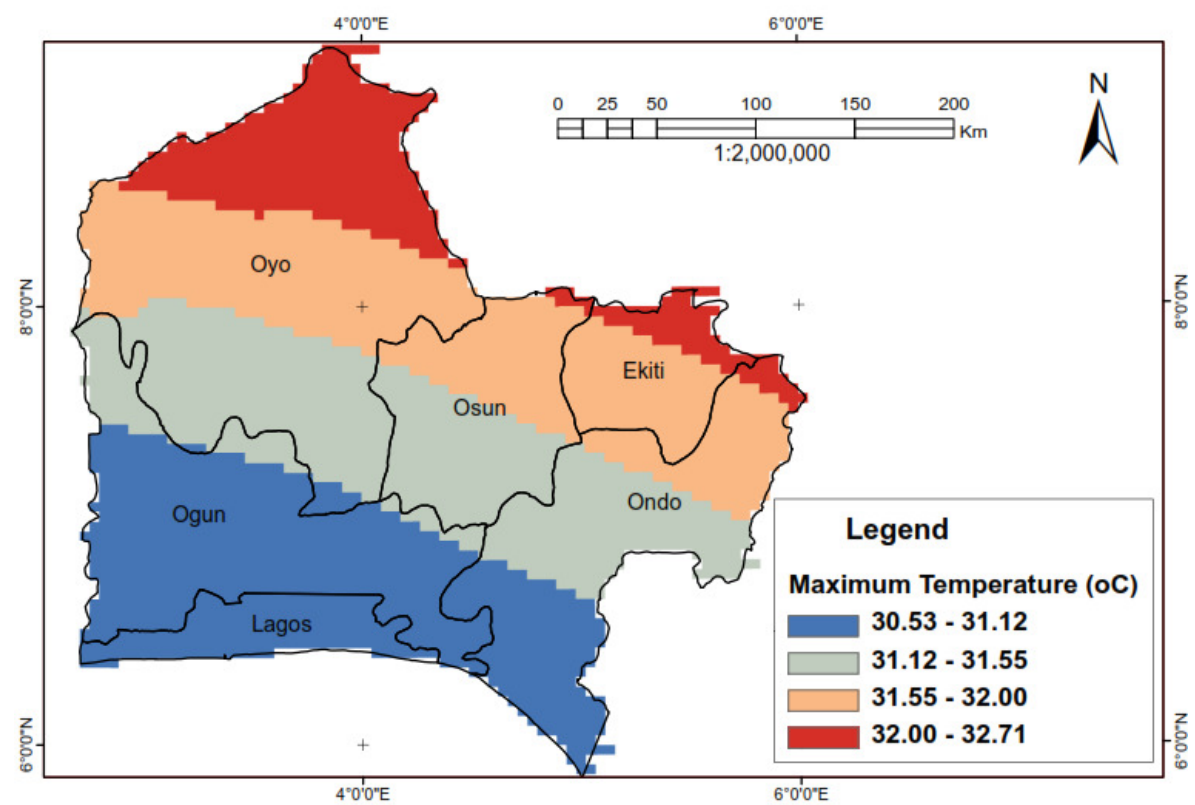

Figure 3: Average maximum temperature in Southwest Nigeria 


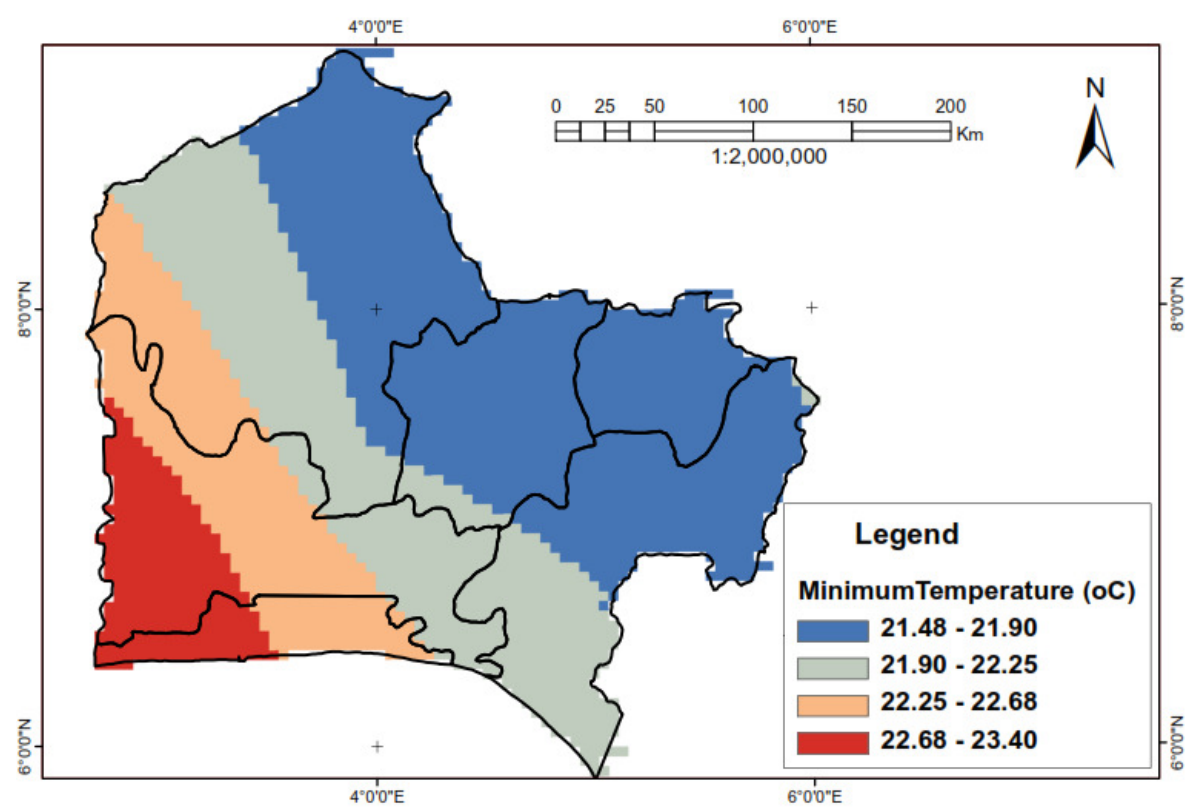

Figure 4: Average minimum temperature in Southwest Nigeria

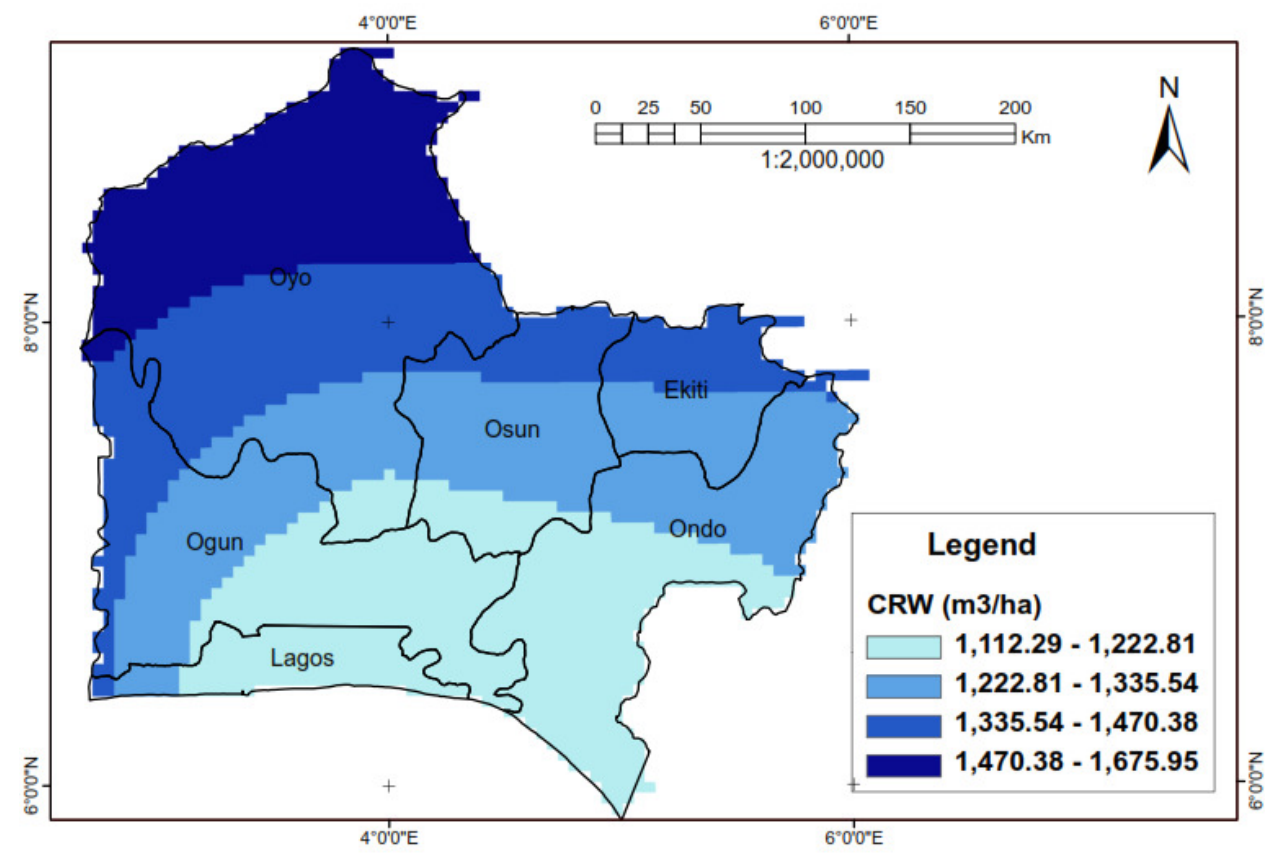

Figure 5: Spatial Distribution of CWR ( $\mathrm{m}^{3} / \mathrm{ha}$ ) for oil palm cultivation across the Southwest Nigeria

Similarly, the effective rainfall (ER) which is the actual amount of moisture available for the crop in different climatic zones of the study area is shown in Figure 6. The values range from $1,223.76 \mathrm{~m}^{3} /$ ha in Humid Forest agroecological zone to $820.39 \mathrm{~m}^{3} / \mathrm{ha}$ in the Derived
Savannah zone. From the result, it shows that available moisture for oil palm's utilization in the Derived Savannah region is far less than moisture present in the Humid forest region of the study area. 


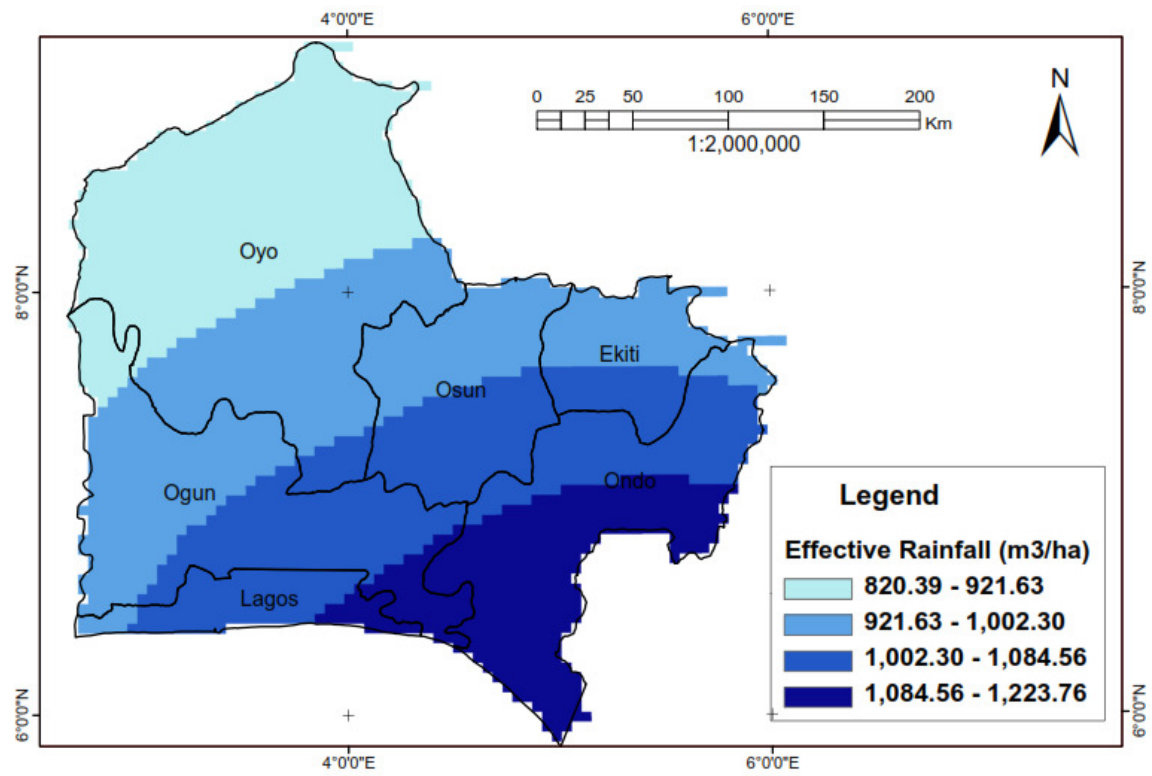

Figure 6: Effective Rainfall in Southwest Nigeria

The irrigation requirement (IR) which is the amount of moisture that is expected to be supplied from irrigation system to replenish the moisture loss through evapotranspiration in order to sustain the growth of the crop in different climatic zones is also shown in Table 2. The values range from $361.2 \mathrm{~m}^{3} / \mathrm{ha}$ in Station 2 that is located in the humid forest agroecological zone to 426 $\mathrm{m}^{3} / \mathrm{ha}$ in Station 1 that is located in the Derived Savannah. The higher value of $743.8 \mathrm{~m}^{3} /$ ha represents Southern Guinea Savannah belt where Ilorin (Station 3) falls within. Figure 7 shows the spatial variation in IR of oil palm across the study area.

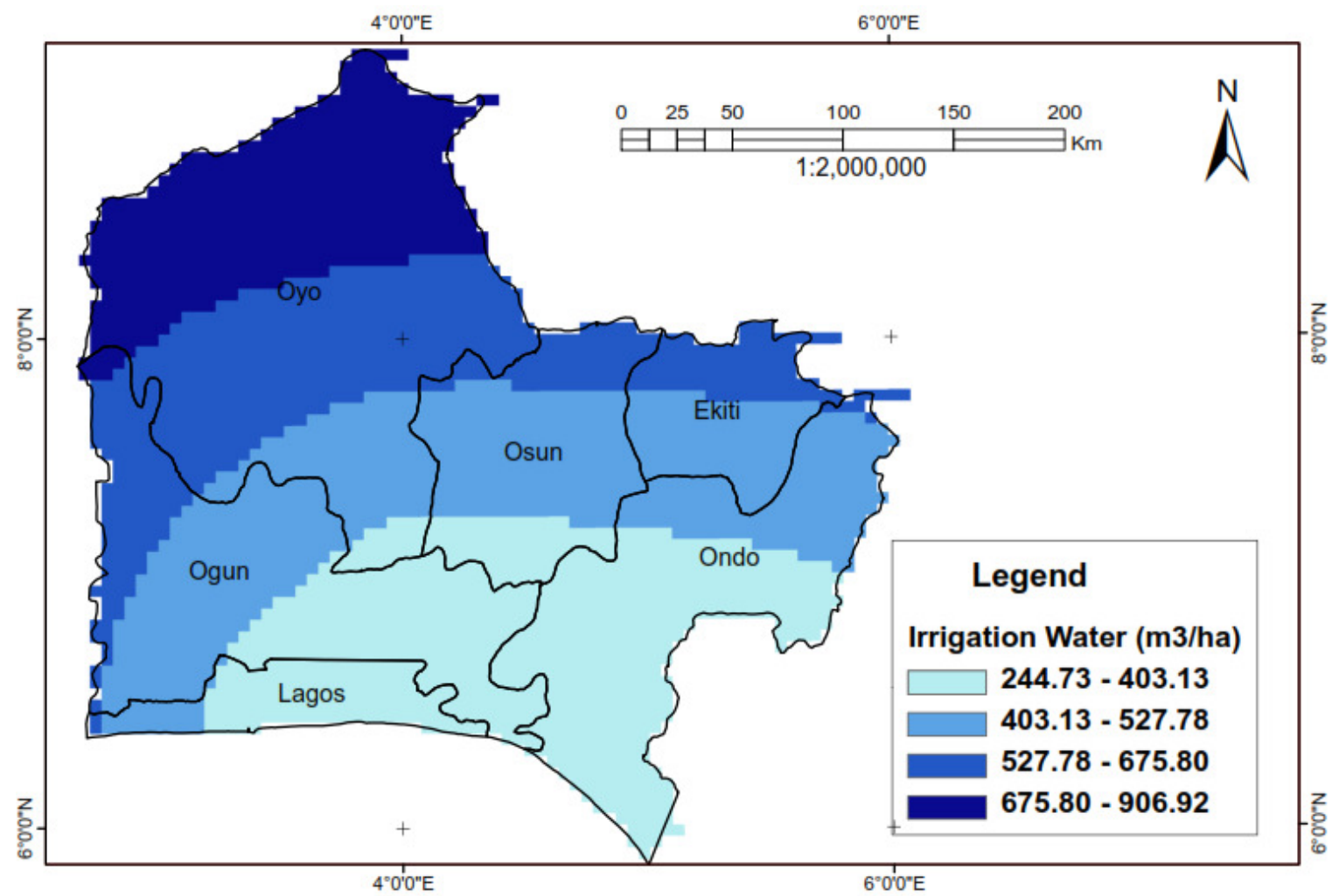

Figure 7: Irrigation Requirement (IR) for oil palm cultivation in Southwest Nigeria 


\section{CONCLUSION}

Crop water requirements of oil palm increase northwards from the humid forest zone to the Sahel savannah zone. Moisture is available for oil palm's utilization in the savannah region but not in abundant quantity as in the southern humid forest zone. Irrigation requirements increase from humid forest agroecological zone to the Sahel savannah zone. Since many crops grown in the savannah agroecological zone of Nigeria is supported through irrigation, oil palm cultivation in commercial scale can easily be extended to the savannah regions with provision of adequate irrigation water.

\section{REFERENCES}

Central Bank of Nigeria/NISER, 1992, The Impact of Structural Adjustment Programme (SAP) on Nigerian Agriculture and Rural Life, Vol. One, CBN/NISER SAP Impact Study
FAO (1986). Early agrometeorological crop yield assessment. FAO plant production and protection, paper 73, Food and Agricultural Organization of the United Nations, Rome.

Gurmit Sigh (1999). Optimal agro-management practices for maximum oil palm productivity; various aspects of large scale oil palm cultivation on peat soil. The Incorporated Society of Planters, Central Sarawak Branch, Sibu, Sarawak, pp. 66-85.

Janick, J. and Paul, R.E., editors. (2008) The Encyclopedia of Fruits and Nuts. Cambridge, MA. CABI.

Kei, K; Mywish, M and Duncan, B (1997).Transformation Versus Stagnation in the Oil Palm Industry: A Comparison between Malaysia and Nigeria". Staff Paper 97-5.

Olagunju, F. I. (2008). Economics of Palm Oil Processing in Southwestern Nigeria. International Journal of Agricultural Economics and RuralDevelopment $\quad 1 \quad$ (2):69-77.

Cite this Article: Isa I, Orewole OM Abayomi TA (2016). Geospatial Assessment of Crop Water Requirement for Yield Optimization of Oil Palm in South West Nigeria. Greener Journal of Agricultural Sciences, 6(7): 226-233, http://doi.org/10.15580/GJAS.2016.8.071316118. 